\title{
A new Cretaceous genus of xyelydid sawfly illuminating nygmata evolution in Hymenoptera
}

\author{
Mei Wang ${ }^{1}$, Alexandr P Rasnitsyn ${ }^{2,3}$, Chungkun Shih ${ }^{1}$ and Dong Ren ${ }^{1 *}$
}

\begin{abstract}
Background: Nygmata are prominent glandular structures on the wings of insects. They have been documented in some extant insects, including several families of Neuroptera and Mecoptera, the majority of Trichoptera, and a few of the hymenopteran Symphyta. However, because nygmata are rarely preserved in compression fossils, their early development and evolution are still enigmatic. For example, the only documented nygmata in the Hymenoptera are on the forewings of the Triassic xyelids Asioxyela paurura and Madygenius primitives.

Results: This study describes and illustrates a new genus and species from the family Xyelydidae, Rectilyda sticta gen. et sp. nov., from the Early Cretaceous Yixian Formation of Duolun County, Inner Mongolia, China. This genus has 1-RS reclival and linearly aligned with 1-M, which is different from all other genera in the Xyelydidae. In addition, R. sticta gen. et sp. nov. has clearly preserved nygmata: four symmetrical nygmata on each forewing and two on each hind wing.

Conclusion: Previous reports of nygmata on the forewings of Triassic xyelids and extant sawflies, together with this new fossil record of nygmata, provide rare insights into their developmental trends, as well as into the evolution of hymenopterans and insects in general.
\end{abstract}

Keywords: Rectilyda, Xyelydidae, Symphyta, Yixian formation, Nygmata, China

\section{Background}

Xyelydidae is an extinct family known from compression fossils ranging in age from the later Early (or earlier Middle) Jurassic to Early Cretaceous. This family, considered to be the most primitive of the Pamphilioidea, plays an important role as an ancestral group in the evolution of the superfamily [1-4]. There are currently 18 species in seven genera recognized within this family $[3,5-10]$, which are summarized in Table 1.

Very few Xyelydidae fossils have been reported from China and only three species have been described from the Jiulongshan Formation of Daohugou, Inner Mongolia, China [8]: Ferganolyda Rasnitsyn, 1983, F. scylla Rasnitsyn, Zhang \& Wang, 2006; F. charybdis Rasnitsyn, Zhang \& Wang, 2006; and F. chungkuei Rasnitsyn, Zhang \& Wang, 2006. In addition, one species from the Yixian Formation of Huangbanjigou, Liaoning, China has been described: Novalyda cretacica Gao, Engel, Shih \& Ren,

\footnotetext{
* Correspondence: rendong@mail.cnu.edu.cn

${ }^{1}$ College of Life Sciences, Capital Normal University, 105 Xisanhuanbeilu, Haidian District, Beijing 100048, China

Full list of author information is available at the end of the article
}

2013. Novalyda cretacica is the only record reported from the Early Cretaceous, representing the youngest record of this family to date [10].

In this study, we describe Rectilyda sticta gen. et sp. nov. from the Yixian Formation of Nanyingpan Village, the Sandaogou Township, Duolun County, Inner Mongolia, China. Based on a unique combination of primitive and more derived characters of this sawfly, we present a new genus and assign it to the family Xyelydidae. This insect fauna lived about $126 \mathrm{Mya}$, and belonged to the famous Jehol biota of the Early Cretaceous [11-14]. According to a survey of the CNUB insect fossil collection, Duolun has yielded many insect fossils, including bugs [15], basal fleas [16], and rare specimens of sawflies. The only sawfly that has been described so far is Hoplitolyda duolunica Gao, Shih, Rasnitsyn \& Ren, 2013, which belongs to Praesiricidae of the superfamily Pamphilioidea. It represents the largest fossil hymenopteran to date, with an estimated body length of $55.0 \mathrm{~mm}$ and wing span of $92.0 \mathrm{~mm}$ [17]. Rectilyda sticta gen. et sp. nov. is, therefore, the second sawfly described from the Duolun locality. 


\section{Table 1 Fossil record of Xyelydidae}

\section{Taxa}

Wing length $(\mathrm{mm})$

Ferganolyda cubitalis Rasnitsyn, 1983

Sai-Sagul, Fergana, Kyrgyzstan; Lower or Middle Jurassic Sogul Formation

F. radialis Rasnitsyn, 1983

F. sogdiana Rasnitsyn, 1983

F. scylla Rasnitsyn, Zhang \& Wang, 2006

F. charybdis Rasnitsyn, Zhang \& Wang, 2006

F. chungkuei Rasnitsyn, Zhang \& Wang, 2006

Mesolyda jurassica Rasnitsyn, 1963

M. sibirica Rasnitsyn, 1983

Novalyda cretacica Gao, Engel, Shih \& Ren, 2013

Prolyda karatavica Rasnitsyn, 1968

P. depressa Rasnitsyn, 1969

P. xyelocera Rasnitsyn, 1968

Rectilyda sticta gen. et sp. nov.

Strophandria grossa Rasnitsyn, 1968

S. moderata Rasnitsyn, 1983

Sagulyda arcuata Rasnitsyn, 1983

S. ferganica Rasnitsyn, 1983

S. magna Rasnitsyn, 1983

Sai-Sagul, Fergana, Kyrgyzstan; Lower or Middle Jurassic Sogul Formation

Sai-Sagul, Fergana, Kyrgyzstan; Lower or Middle Jurassic Sogul Formation

Daohugou, Inner Mongolia, China; Middle Jurassic Jiulongshan Formation

Daohugou, Inner Mongolia, China; Middle Jurassic Jiulongshan Formation

8 as preserved

16.6

Daohugou, Inner Mongolia, China; Middle Jurassic Jiulongshan Formation

Mikhailovka, Karatau, southern Kazakhstan; Upper Jurassic Karabastau Formation

15.4 (male) 9.0 (female)

Uda, Buryat Republic, Siberia; Upper Jurassic Uda Formation

9

Huangbanjigou, Liaoning, China; Lower Cretaceous Yixian Formation

Mikhailovka, Karatau, southern Kazakhstan; Upper Jurassic Karabastau Formation

Mikhailovka, Karatau, southern Kazakhstan; Upper Jurassic Karabastau Formation

Mikhailovka, Karatau, southern Kazakhstan; Upper Jurassic Karabastau Formation

Nanyingpan, Inner Mongolia, China; Lower Cretaceous Yixian Formation

Mikhailovka, Karatau, southern Kazakhstan; Upper Jurassic Karabastau Formation

Mikhailovka, Karatau, southern Kazakhstan; Upper Jurassic Karabastau Formation

Sai-Sagul, Fergana, Kyrgyzstan; Lower or Middle Jurassic Sogul Formation

Sai-Sagul, Fergana, Kyrgyzstan; Lower or Middle Jurassic Sogul Formation

Sai-Sagul, Fergana, Kyrgyzstan; Lower or Middle Jurassic Sogul Formation

Mikhailovka, Karatau, southern Kazakhstan; Upper Jurassic Karabastau Formation 


\section{Methods}

The specimen was examined and then photographed, either dry or wetted with $95 \%$ ethanol, using a Leica MZ 16.5 dissecting microscope (Leica, Wetzlar, Germany) with a Leica DFC500 digital camera attached. The line drawings were prepared using Adobe Illustrator CS2 and Adobe Photoshop CS5 software. The wing venation nomenclature used in this article was modified after Rasnitsyn [1,2]. The type material described is deposited in the Key Lab of Insect Evolution and Environmental Changes, College of Life Sciences, Capital Normal University, in Beijing, China (CNUB; Ren Dong, Curator).

No specific permits were required for collection of the insect fossils, including the materials from Nanyingpan Village, Sandaogou Township, Duolun County, Inner Mongolia, China.

\section{Results}

Description of the specimens

Hymenoptera Linnaeus, 1758.

Pamphilioidea Cameron, 1890.

Xyelydidae Rasnitsyn, 1968.

Rectilyda Wang, Rasnitsyn, Shih \& Ren, gen. nov.

\section{Etymology}

The generic name is a combination of the Latin "Rect-", meaning straight (referring to the alignment of 1-RS and 1-M), and Lyda, a junior synonym of Pamphilius Latreille, 1802, often used as a suffix for generic names in Pamphilioidea. Gender feminine.

\section{Diagnosis}

Antenna with about 17 segments; the third antennal segment shorter than remaining segments combined; flagellomeres nearly as long as wide, becoming narrower and shorter towards the apex. Mandibles strong, with at least one small inner tooth. Forewing with SC bifurcate; pterostigma narrow and long, sclerotized completely; 1-RS reclival, as long as $1-\mathrm{M}$ and linearly aligned with $1-\mathrm{M}$; $1-\mathrm{M}$ nearly equal to $2-\mathrm{M}$ in length; cell $3 \mathrm{r}$ at least 1.5 times as long as cells $1 \mathrm{r}$ and 2r. Hind wing with SC1 and $\mathrm{SC} 2$ present; crossvein $\mathrm{m}$-cu distal to middle of cell $\mathrm{rm}$; cu-a before middle of cell mcu.

\section{Remarks}

We assign Rectilyda gen. nov. to Xyelydidae mainly based on three primitive characters. This recognition is by necessity, as the family is paraphyletic and reclassification into one or several monophyletic parts is complicated under the current state of knowledge [4,7]. The primitive characters are: 1) SC bifurcate in the forewing; 2) $\mathrm{M}+\mathrm{Cu}$ smoothly bent; 3 ) cell $1 \mathrm{mcu}$ relatively large and 1cu-a located distad middle of cell $1 \mathrm{mcu}$. Rectilyda differs from other members of Xyelydidae in having
1-RS aligned with, and as long as, 1-M and the third antennal segment shorter than remaining segments combined. Other xyelydids always have 1-RS proclival, distinctly angled with 1-M and much shorter than 1-M; $1-\mathrm{RS}$ is rarely subequal to $1-\mathrm{M}$, and the third antennal segment is relatively longer and thicker than the subsequent ones combined.

Rectilyda sticta Wang, Rasnitsyn, Shih \& Ren, sp. nov.

\section{Diagnosis}

As for the genus by monotypy.

\section{Etymology}

The specific name is derived from the Greek word "stictos" meaning spotted or punctured, referring to the nygmata on the wings.

\section{Holotype}

CNU-HYM-LB-2012125, deposited in CNUB, sex unknown, a well-preserved sawfly, with an almost complete body, including parts of the antennae, both forewings, hind wings, and parts of the legs.

\section{Locality and horizon}

Nanyingpan Village, Sandaogou Township, Duolun County, Inner Mongolia, China. Yixian Formation, Early Cretaceous.

\section{Description}

Color not reliable because of absence of counterpart fossil; as preserved, body infuscate, with mouthparts, antennae, part of mesothorax and abdominal segments 4-8 darker; forewing somewhat infuscate sub-basally, with pterostigma dark, especially in costal area along veins (Figure 1A). Entire body and all legs (excluding tarsi) with dense, long, dark setae.

Head: relatively large, transverse, ovate, about 1.23 times as wide as long, nearly as wide as mesothorax (0.9 times), with eyes and ocelli indistinguishable; mandibles small, sickle-shaped, with at least one inner tooth; other detailed structures of mouthparts obscured (Figure 1B). Antennae with about 17 segments (including pedicel), pedicel as wide as $3^{\text {rd }}$ segment, the $3^{\text {rd }}$ one $(1.45 \mathrm{~mm}$ in length) shorter than remaining segments combined (3.3 $\mathrm{mm}$ in length), thickest point of $3^{\text {rd }}$ segment $0.46 \mathrm{~mm}$ wide, $4^{\text {th }}$ segment $0.21 \mathrm{~mm}$ wide, apical flagellomere $0.09 \mathrm{~mm}$ wide; flagellomeres gradually shorter and narrower towards apex, each flagellomere becoming flat and subquadrate (Figure 1E).

Thorax: slightly wider than head, anterior edge of mesoscutum nearly straight (Figure 2A), mesothorax covered with some short setae (Figure 1F).

Legs (Figures 1D and 2A): coxae trapezoidal (hind coxae 0.87 times as long as wide); two trochanters in hind legs, rectangular, covered with dense bristles, proximal 

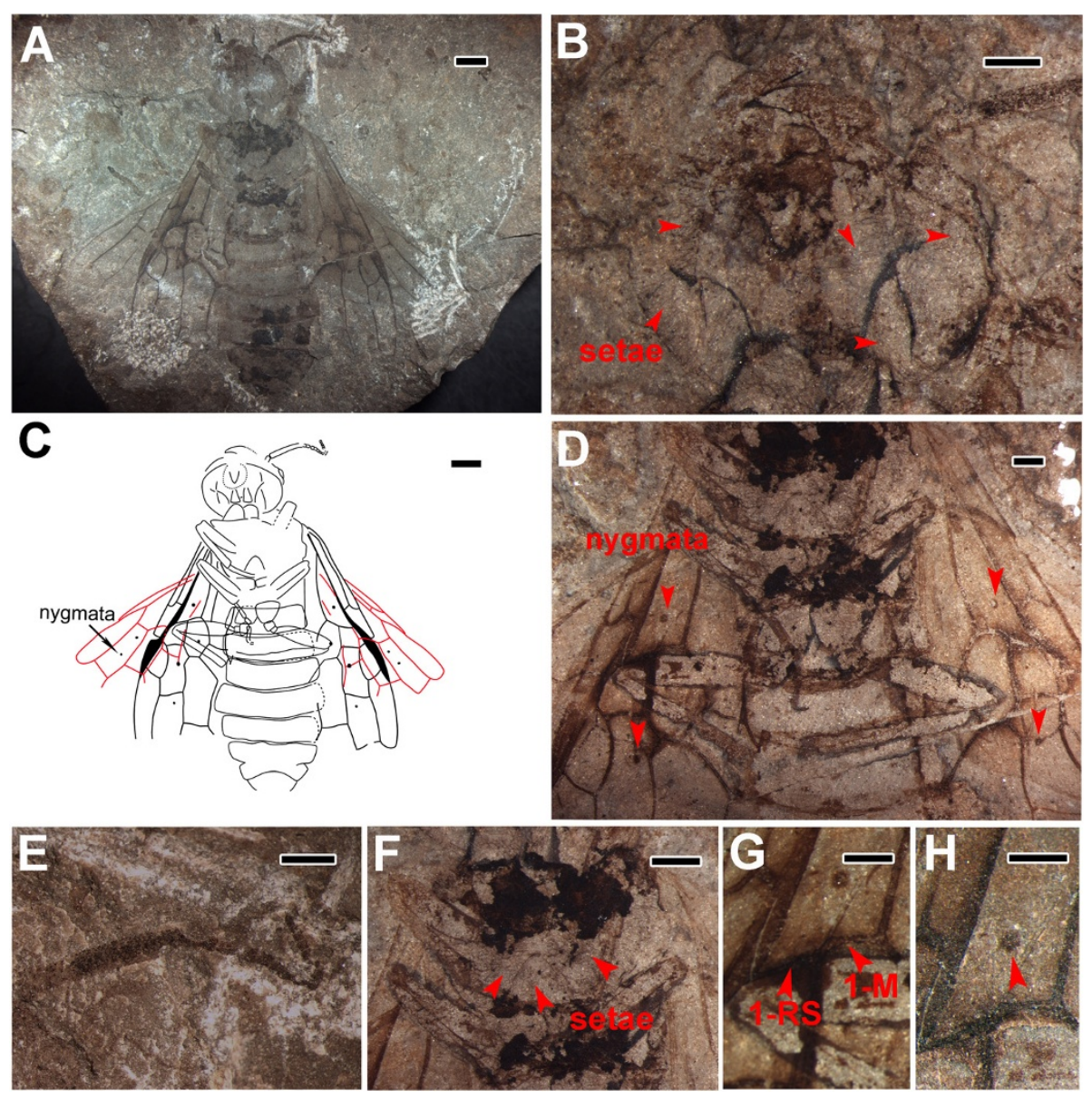

Figure 1 Rectilyda sticta gen. et sp. nov. Holotype, CNU-HYM-LB2012125. A, Habitus. B, Head (with addition of alcohol). C, Line drawing. D, Part of legs (with addition of alcohol). E, Part of antennae (with addition of alcohol). $\mathbf{F}$, Setae on mesothorax. G, Part of left forewing with 1-RS aligned with 1-M. H, nygma on cell 1rm. Scale bars: $2 \mathrm{~mm}$ in $\mathbf{A}$ and $\mathbf{C} ; 0.5 \mathrm{~mm}$ in $\mathbf{B}, \mathbf{D}, \mathbf{E}, \mathbf{F}$ and $\mathbf{G} ; 0.2 \mathrm{~mm}$ in $\mathbf{H}$.

one about 1.82 times as long as and 1.42 times as wide as distal one. Femora fusiform, about 3.5 times as wide as long; hind femora shorter than mesothorax; fore and mid femora narrower than hind femora. Tibiae comparatively narrow and long; hind tibiae longer than fore and mid tibiae and about 1.2 times as long as hind femora. Tarsi incompletely preserved, mid claw apparently with small submedial tooth.

Wing: (Figure 2B) with SC bifurcate, SC1 bent gently upward and intersecting C; SC2 short, meeting R slightly before SC1 and meeting $\mathrm{C}$, subperpendicular to R; R nearly straight, gently bent anteriorly in distal half, thickened before pterostigma; pterostigma narrow ( $0.57 \mathrm{~mm}$ wide), sclerotized completely. 1-RS reclival, inclined towards wing base, aligned with and meeting 1-M, about equal in length (Figure 1G). R between SC2 and 1-RS about 0.7 times as long as 1-RS and 1-M combined; 1r-rs inclined, 0.34 times as long as $2 \mathrm{r}-\mathrm{rs} ; 2 \mathrm{r}$-rs bent towards wing apex; $\mathrm{M}+\mathrm{Cu}$ bent smoothly; $2 \mathrm{r}-\mathrm{m}$ inclined towards wing base and separated from 2r-rs by 0.7 times of its own length, located distad middle of cell $2 \mathrm{mcu}$; $3 \mathrm{r}-\mathrm{m}$ separated from apex of cell $3 \mathrm{r}$ by 0.67 of its length; $2 \mathrm{r}-\mathrm{m}$ as long as $3 \mathrm{r}-\mathrm{m}$; $2-\mathrm{M}$ nearly equal to $1-\mathrm{M} ; 1 \mathrm{~m}$-cu 0.87 times as long as $2-\mathrm{M}$ and about 0.57 times as long as $2-\mathrm{Cu} ; 2-\mathrm{M}$ and $3-\mathrm{M}$ meeting at distinct obtuse angle; $1 \mathrm{cu}-\mathrm{a}$ bent distinctly towards wing apex, nearly as long as $2-\mathrm{Cu}$ and placed apparently distad middle of cell $1 \mathrm{mcu} ; 2 \mathrm{~m}$-cu curved, almost at middle of cell $3 \mathrm{rm}$; cell $2 \mathrm{rm}$ almost equal to 3 $\mathrm{rm}$ in length, and 0.75 times as long as and 0.73 times as wide as cell $2 \mathrm{mcu}$. Four symmetrical nygmata present (Figure 1C) in cells 1rm (Figure 1D and H), 1mcu, 2rm (Figure 1D) and 3rm. In right hind wing (Figure 2C), vein SC well-developed with two branches. Cell $r$ widely rounded apically; 1-RS slightly longer than 1-M; crossvein $1 \mathrm{r}-\mathrm{m}$ distant from bases of both RS and $\mathrm{M}$, about 0.65 times as long as 1-RS; 3r-m near apex of cell $r$, crossvein $\mathrm{m}-\mathrm{cu}$ long, joining 2-M distal of midlength of cell rm, separated from 3r-m by nearly its length. Crossvein cu-a 


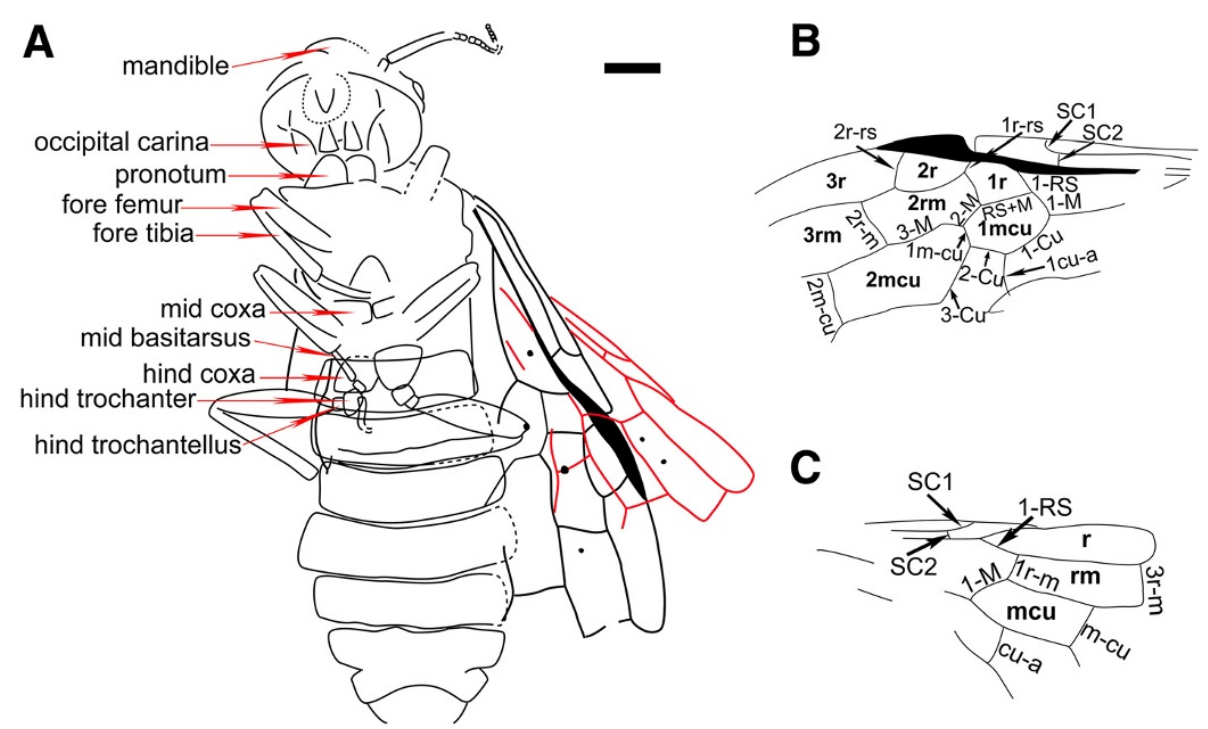

Figure 2 Line drawings of Rectilyda sticta gen.et sp. nov. Holotype. A, Body. B, Left forewing. C, Right hind wing. Scale bars: 2 mm.

slightly curved towards wing apex, proximal to midlength of cell mcu. Two symmetrical nygmata in cell $\mathrm{rm}$ (Figure 1C).

Abdomen: eight abdominal terga visible, fourth tergum slightly longer than other segments. Genitalia indistinct (sex unknown).

\section{Dimensions of holotype (in $\mathrm{mm}$ )}

CNU-HYM-LB-2012125: Body length (excluding antennae) 24.0, head length without mandible 4.9, width 6.1, forewing length up to end of cell $3 \mathrm{r}$ 17.5, as preserved (full length, ca. 20.0).

\section{Discussion}

Unique characters in Rectilyda sticta gen. et sp. nov

Since most xyelydids have been described from detached wings without preserved bodies, we summarize the reported data of wing lengths for all species of xyelydids in Table 1. The data show that forewing lengths (up to the end of cell 3r) vary substantially from $5 \mathrm{~mm}$ in Prolyda xyelocera Rasnitsyn, 1968 to $17.5 \mathrm{~mm}$ in $R$. sticta gen. et sp. nov. The data show that $R$. sticta is the second largest xyelydid fossil recorded so far, only smaller than the relatively little-known Sagulyda magna Rasnitsyn, 1983, from the late Early or early Middle Jurassic of Central Asia.

In addition, the direction of 1-RS varies significantly; 1-RS is normally proclival (e.g., in Prolyda, Xyelyda, Strophandria, and Ferganolyda) or vertical (e.g., in Sagulyda and Mesolyda), resulting in the angles between 1-RS and 1-M ranging from $86.8^{\circ}$ to $140^{\circ}$ [3]. However, in the vast and extensive CNUB collection of more than 100 xyelydid fossils from China, $R$. sticta is the only one to date with 1-RS reclival. It also has 1-RS aligned linearly with 1-M (Figure 1G), thus forming a "T" shape, which is normally present in the Apocrita of the Hymenoptera [18,19]. Furthermore, the most basal sawflies usually possess SC in both wing pairs [1,2]. Xyelydidae, as the most basal and putative stem group (paraphyletic) in the Superfamily Pamphilioidea [4], have plesiomorphic characters with SC bifurcate in their forewings, but SC absent in the hind wings. Rectilyda sticta, however, has SC in both fore- and hind wings. In summary, unique and exceptional wing structures indicate that $R$. sticta has a combination of primitive and more derived characters highlighting its transitional role in the Xyelydidae.

As aforementioned, Hoplitolyda duolunica Gao, Shih, Rasnitsyn \& Ren, 2013, collected from Sandaogou Township, Duolun County, is thus far considered to be the largest sawfly in the Praesiricidae, possibly in Symphyta [17]. Intriguingly, $R$. sticta is the second largest fossil specimen in the family Xyelydidae. It is unknown whether this phenomenon of gigantism is just a coincidence due to sampling bias from limited collection of fossil specimens or if it was caused by some factors in the ecosystem and environment at this locality. Gao et al. [17] discussed possible reasons why Hoplitolyda duolunica in the Mesozoic could have reached such a large size and stated that it might have been caused by food availability or sexual selection. For now, however, it is unclear if gigantism was a natural phenomenon at the Duolun locality and what factors could have resulted in giant body sizes, pending future collection of more large insect fossils from Duolun. 


\section{About nygmata in the holometabola}

Nygmata on the wings of various Holometabola have been known (often under different names) since at least the later part of the $19^{\text {th }}$ century. Martynov $[20,21]$ made the first comprehensive study of nygmata using the term "facetic organs" to refer to McLahlan's (1874-1880) "corneous points" as the first record that recognized these structures as very stable in their positions in respect to particular veins and forks in the wings of Trichoptera. Martynov demonstrated histologically that the "facetic organs" of Trichoptera were glandular in nature (he compared them with the wax glands of aphids and bees), which were most developed in the young adults (just molted), but degenerated in older adults. He also described the structures as being specific to Holometabola, but secondarily lost in Coleoptera, Diptera, and Lepidoptera. Of particular importance, he considered that numerous precursors found in Corydalidae (Megaloptera) indicate their possible abundance in the wings of ancestral Holometabola. However, studies and publications by Martynov [20,21] have not been broadly noticed, and even as recent as 1989 to 1991, nygmata have sometimes been referred to as "presumed sensory spots" [22,23]. However, the majority of authors recognize their glandular nature [24-26]. The idea of nygmata as a groundplan character of Holometabola has been recently reiterated by Minet et al. [27].

Nygmata are rarely present in compression fossils due to the nature of preservation. To date, nygmata have been reported on fossil wings in Permochoristidae, Permotanyderidae, Parachoristidae and Panorpidae of Mecoptera [4,28,29], Parasialidae of Megaloptera [30], Permithonidae of Neuroptera [29], Microptysmatidae of Trichoptera [29] and in Xyelidae of Hymenoptera (Figure 3B) [1,31]. In addition, Wang et al. recently reported nygmata in fossil neuropterans [32,33] and Liu et al. in fossil megalopterans [34].

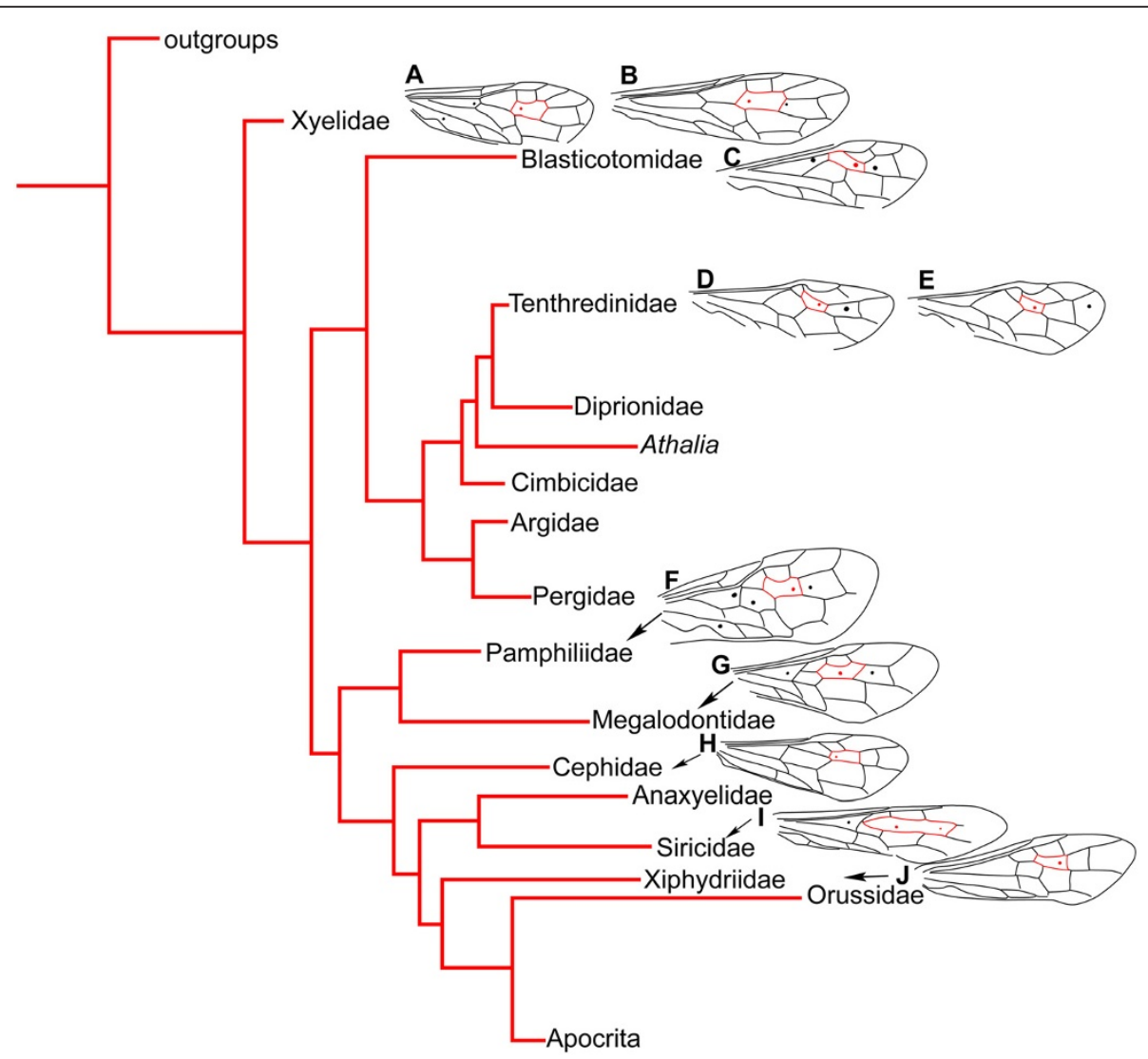

Figure 3 Cladogram of extant basal Hymenoptera after Ronquist et al. (2012, Figure 3, slightly modified), with relevant forewing venation containing nygmata among extant taxa mapped onto figure. A, Macroxyela ferruginea Say, 1824 (Xyelidae). B, Megaxyela major Cresson, 1880 (Xyelidae). C, Blasticotoma filiceti Klug, 1834 (Blasticotomidae). D, Empria candidata Fallén, 1808 (Tenthredinidae). E, Empria formosana Prous \& Heidemaa, 2012 (Tenthredinidae). F, Onycholyda amplecta Fabricius, 1804 (Pamphiliidae). G, Megalodontes cephalotes Fabricius, 1781 (Megalodontidae). H, Cephus pygmeus Linné, 1767 (Cephidae). I, Tremex columba Linné, 1763 (Siricidae). J, Xiphydria camelus Linné, 1758 (Xiphydriidae). Wing drawings based on images referred to in Table 2. 
Table 2 Summary of nygmata positions for extant Symphyta

$1 \mathrm{rm} 2 \mathrm{rm} 3 \mathrm{rm} 1 \mathrm{mcu} 2 \mathrm{mcu} 1 \mathrm{cua} 1 \mathrm{a} 1 \mathrm{rm} \underset{+3 \mathrm{rm}}{2}$ cua $1 \mathrm{a}$ References

\section{Xyelidae}

Macroxyela ferruginea (Say, 1824)

Pleroneura coniferarum

(Hartig, 1837)

Xyela julii (Dalman, 1820)

\section{Blasticotomidae}

Blasticotoma filiceti Klug, 1834

\section{Argidae}

Arge ustulata (Linné, 1758)

Aprosthema sp.

Scobina stigmaticollis (Klug, 1834)

Pachylota audouinii

Westwood, 1841

\section{Pergidae}

Perga affinis Kirby, 1882

Lophyrotoma interrupta

(Klug, 1814)

Phylacteophaga eucalypti

Froggatt, 1899

\section{Cimbicidae}

Cimbex connatus (Schrank, 1776)

Zarea fasciata

Pachylosticta albiventris

Klug, 1824

Corynus amoena (Klug, 1834)

Corynus obscura (Fabricius, 1775)

\section{Diprionidae}

Neodiprion sertifer

(Geoffroy, 1785)

\section{Tenthredinidae}

Croesus latipes (Villaret, 1832)

Pachynematus sp.

Hemichroa australis

(Serville, 1823)

Selandria sp.

Dolerus vestigialis (Klug, 1818)

Dolerus gonager (Fabricius, 1781)

Eriocampa sp.

Sciapterix consobrina (Klug, 1816)

Empria candidata (Fallén, 1808)

Empria takeuchii Prous,

Heidemaa, 2011

Empria formosana Prous, Heidemaa, 2012

Blennallantus compressicornis Wei, 1998
$(+) \quad(+)$

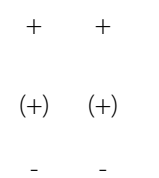

$-+$

(+) (+) $\quad(+)$ http://www.morphbank.net/?id=102897

http://www.morphbank.net/?id=102898

Orig.

Orig.

+ Orig.

- Orig.

- Orig.

- Orig.

Orig.
- Orig.

Orig.

Orig.
- Orig.

- Orig.

- Orig.

- Orig.

Orig. 
Table 2 Summary of nygmata positions for extant Symphyta (Continued)

\begin{tabular}{|c|c|c|c|c|c|c|c|c|c|c|c|c|}
\hline $\begin{array}{l}\text { Tenthredo bifasciata rossii } \\
\text { (Panzer, 1803) }\end{array}$ & + & + & + & - & - & - & - & - & + & + & - & Orig. \\
\hline Hetererthrus vagans (Fallen, 1808) & - & - & - & - & - & - & - & - & - & - & - & Orig. \\
\hline Athalia rosae (Linné, 1758) & + & + & - & - & - & - & - & - & - & - & + & $\begin{array}{l}\text { Orig., http://www.morphbank.net/?id=102498 } \\
\text { http://www.morphbank.net/?id=102497 }\end{array}$ \\
\hline \multicolumn{13}{|l|}{ Pamphiliidae } \\
\hline Cephalcia abietis (Linné, 1758) & + & + & + & - & + & - & + & - & + & + & + & Orig. \\
\hline $\begin{array}{l}\text { Acantholyda erythrocephala } \\
\text { (Linné, 1758) }\end{array}$ & + & + & + & - & - & + & + & + & + & + & + & Orig. \\
\hline $\begin{array}{l}\text { Pamphilius pallipes Zetterstedt, } \\
1838\end{array}$ & + & + & + & - & - & - & + & - & + & + & + & Orig. \\
\hline $\begin{array}{l}\text { Onycholyda amplecta } \\
\text { (Fabricius, 1804) }\end{array}$ & + & + & + & + & - & - & + & & + & $(+)$ & $(+)$ & $\begin{array}{l}\text { http://www.morphbank.net/?id=102851 } \\
\text { http://www.morphbank.net/?id=102852 }\end{array}$ \\
\hline \multicolumn{13}{|l|}{ Megalodontesidae } \\
\hline Megalodontes sp. & + & + & + & - & - & - & - & - & - & - & - & Orig. \\
\hline \multicolumn{13}{|l|}{ Cephidae } \\
\hline Syrista parreyssii (Spinola, 1843) & - & + & - & - & - & - & - & - & - & - & - & Orig. \\
\hline Calameuta pallipes (Klug, 1803) & - & - & - & - & - & - & - & - & - & - & - & Orig. \\
\hline Cephus pygmeus (Linné, 1767) & & + & & - & - & - & - & - & - & - & - & $\begin{array}{l}\text { http://www.morphbank.net/?id=102959 } \\
\text { http://www.morphbank.net/?id=102960 }\end{array}$ \\
\hline \multicolumn{13}{|l|}{ Anaxyelidae } \\
\hline Syntexis libocedrii Rohwer, 1915 & - & - & - & - & - & - & - & - & - & - & - & Orig. \\
\hline \multicolumn{13}{|l|}{ Siricidae } \\
\hline Urocerus gigas (Linné, 1758) & + & + & + & & 2 & + & - & - & 2 & + & - & Orig. \\
\hline Sirex noctilio Fabricius, 1793 & + & + & + & & 2 & + & - & - & 2 & - & - & Orig. \\
\hline $\begin{array}{l}\text { Tremex fuscicornis } \\
\text { (Fabricius, 1787) }\end{array}$ & + & + & + & - & + & + & - & & 2 & + & - & Orig. \\
\hline Tremex columba (Linné, 1763) & + & + & + & - & - & + & - & - & + & - & - & $\begin{array}{l}\text { http://www.morphbank.net/?id=102782 } \\
\text { http://www.morphbank.net/?id=102763 }\end{array}$ \\
\hline \multicolumn{13}{|l|}{ Xiphydriidae } \\
\hline Xiphydria camelus (Linné, 1758) & + & + & - & - & - & - & - & & + & & & $\begin{array}{l}\text { Orig., http://www.morphbank.net/?id=102720 } \\
\text { http://www.morphbank.net/?id=102721 }\end{array}$ \\
\hline $\begin{array}{l}\text { Euxiphydria potanini } \\
\text { (Jakowlew, 1891) }\end{array}$ & + & + & - & - & - & - & & & + & & & Orig. \\
\hline Orussidae spp. & - & - & - & - & - & - & - & & - & & & Orig. \\
\hline
\end{tabular}

(+) nygma weakly developed.

\section{Nygmata evolution in hymenoptera}

Of the extant Hymenoptera, nygmata are present only in Symphyta [35]. We examined various lower Apocrita (Orussidae, Stephanidae, Trigonalidae, Megalyridae and Gasteruptiidae s.l.) and were unable to find any nygmata (APR, pers. obs. 2014). Our observations, including the numbers and positions of nygmata for Symphyta, are summarized in Table 2. The data confirm that nygmata occur in almost every family of Symphyta, but not in every genus. Nygmata are particularly weakly visible, or apparently lost, in small sawflies, such as Xyela Dalman, Pleroneura Konow (Xyelidae), Heterarthrus Stephens (Tenthredinidae), etc. This may explain why nygmata are not detectable in Syntexis Rohwer, 1915, the only living representative of Anaxyelidae. On the other hand, there are sawflies of large body size without any visible nygmata, e.g., Neodiprion sertifer Geoffroy, 1785, Diprionidae.

Generally, the families with the highest number of cells with nygmata are in the extant Pamphiliidae (up to five in the forewing and four in the hind wing) and Siricidae (up to five in the forewing and only two in the hind wing). The lowest number of cells with nygmata is recorded in the Cephidae (one and zero for the foreand hind wing, respectively). Other families take intermediate positions. Even the most basal hymenopteran family, Xyelidae, shows a modest development of nygmata (up to three and two for the fore- and hind wing, 
respectively), unless considering the four and two rudimentary nygmata in Pleroneura Konow, 1897. The nygmata of Symphyta are characteristically found in the forewing cells of $1 \mathrm{rm}$ and $2 \mathrm{rm}$ and in the hind wing cell of $2+3 \mathrm{rm}$. Nygmata in the forewing $2 \mathrm{rm}$ and hind wing $2+3 \mathrm{rm}$ cells are the most stable. Minet et al. [27] have argued that nygmata located in the RS-M interspace are groundplan autapomorphies of the entire Holometabola (referring to Xyelidae as an example in Hymenoptera). In the case of venational reduction, the aforementioned stable set of nygmata would be useful for exploring cell and vein homology, provided the nygmata are persistent.
Of the fossil Xyelidae, both Triassic Asioxyela paurura Rasnitsyn, 1969, and Madygenius primitives Rasnitsyn, 1969, have six nygmata in forewing cells 1rm, 1cua, 1a, 2rm, 3rm, and 2mcu [1,31] (Figure 4B). This implies that the low number of nygmata in the living Xyelidae (Table 2) is the result of a secondary reduction. In fact, Xyelidae, the most basal hymenopteran family, is the most plesiomorphic in that respect as well. Rectilyda sticta gen. et sp. nov. in the family of Xyelydidae, the only other sawfly fossil with nygmata preserved, has four symmetrical nygmata on each forewing (in cells $1 \mathrm{rm}$, $2 \mathrm{rm}, 3 \mathrm{rm}$ and $1 \mathrm{mcu}$ ) and two in the hind wing, both in the cell $2+3 \mathrm{rm}$ (Figure $4 \mathrm{C}$ ). The latter two nygmata in

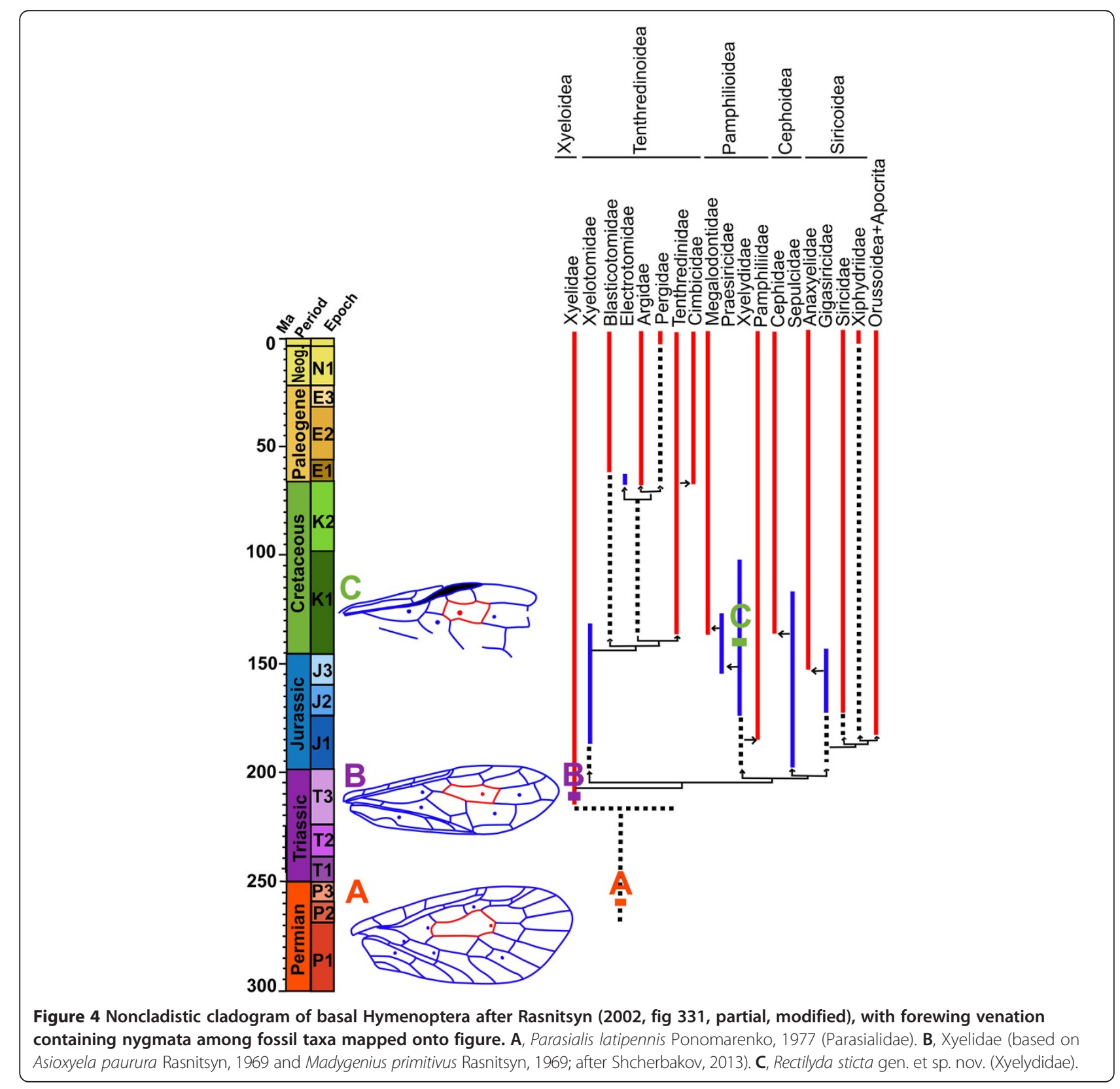


one cell of the hind wing probably pertain to an origin as isolated cells of $2 \mathrm{rm}$ and $3 \mathrm{rm}$, as is still retained by many members of the Xyelidae. The siricid forewings are analogous; their cells $2 \mathrm{rm}$ and $3 \mathrm{rm}$ each preserve a nygma, even if a delimiting crossvein $2 \mathrm{r}-\mathrm{m}$ is lost (as in Tremex Jurine, 1807).

The family Xyelidae appeared in the Middle or Upper Triassic of Kyrgyzstan in Central Asia [1,2] and the Upper Triassic of Australia [36,37], South Africa [38] and Argentina [39]. It is considered the most basal group in the phylogeny of Symphyta and in Hymenoptera $[2,4,7,40,41]$. Shcherbakov [31,42] considers Permian Parasialidae Ponomarenko, 1977 (Figure 4A) [Suborder Archimegaloptera Engel, 2004, Order Panmegaloptera Shcherbakov, 2013 (=Megaloptera s.l., i.e. sensu Latreille, 1802)] to be ancestors of Hymenoptera, because they are similar to symphytans in venation, pterostigma, and nygmata. However, this assumption contradicts several characters implying Hymenoptera to be a sister group of all the remaining Holometabola. In particular, the ovipositor structure of other Holometabola have synapomorphies in having the second valves (gonapophyses of the $9^{\text {th }}$ segment or dorsal stylets) reduced, and the third valves (outer valves, derivatives of valvifers 2) fused and working as an intromittent organ inserted into the substrate during oviposition. In contrast, the groundplan hymenopteran ovipositor retains a pterygotan ground plan in that its $2^{\text {nd }}$ valves are developed and functional, and the $3^{\text {rd }}$ valves are free while serving as saw-like sheaths. Additionally, current molecular phylogenies mainly show that Hymenoptera is a sister group of the remaining Holometabola [41,43-48]. Nevertheless, wings of the Parasialidae (Figure 4A) could be taken as a rough model of a hymenopteran ancestor until a more likely ancestral group, the extinct order Palaeomanteida $[2,49]$, is studied for nygmata in the future.

There is a general trend of a decreasing number of nygmata during the evolution of hymenopteran wings. This is evidenced by the seven forewing nygmata of Parasialis latipennis Ponomarenko, 1977 in Parasialidae in the Permian (Figure 4A), six nygmata for Asioxyela paurura and Madygenius primitives in Xyelidae in the Triassic [1,31] (Figure 4B), and one to three nygmata in most of the extant species among Symphyta (Figure 3A-E, G-J), except for Pamphiliidae and Siricidae, which have five (Figure 3F). Rectilyda sticta gen.et sp. nov., with its four nygmata, appears to have a transitional role in this general trend.

\section{Conclusions}

A thorough review of the various types of nygmata in extant and extinct Hymenoptera suggests that in this order, the nygmata have had stable positions in the forewing cell of $2 \mathrm{rm}$ and hind wing cell of $2+3 \mathrm{rm}$. In addition, the evolution of the Hymenoptera has generally resulted in a decrease in the number of nygmata. Most importantly, $R$. sticta gen. et sp. nov., with four nygmata, bridges the gap and provides rare insights into the trend of nygmata development over time, as well as the evolution of insects in general and of hymenopterans in particular.

\section{Availability of supporting data}

The data set supporting the results of this article is available in the Dryad repository, doi:10.5061/dryad.v561f [50].

\section{Ethics}

The authors declare that the study makes no uses of human, clinical tools and procedures, vertebrate and regulated invertebrate animal subjects and/or tissue, and plants.

\section{Competing interests}

The authors declare that there are non-financial competing interests (political, personal, religious, ideological, academic, intellectual, commercial or any other), no competing interests in the manuscript.

\section{Authors' contributions}

MW, APR, CKS carried out the fossil processing, photography and figure preparation. MW, CKS, DR conceived and designed the study. MW, APR, CKS, DR participated in the data analysis, interpretation, manuscript drafting, modification and finalization. All authors read and approved the final manuscript.

\section{Acknowledgments}

We sincerely thank the editor and two anonymous reviewers for their critical review and constructive suggestion. We acknowledge Dr. Taiping Gao for his useful advice and discussions on this article. Our thanks also go to Dr. Steven R. Davis for his copyediting and improving of this article. This research was supported by the National Basic Research Program of China (973 Program; 2012CB821906), the National Natural Science Foundation of China (No. $31230065,41272006)$, Great Wall Scholar and KEY project of the Beijing Municipal Commission of Education (KZ201310028033), Program for Changjiang Scholars and Innovative Research Team in University (IRT13081); For APR, the work was additionally supported by the Presidium RAS Program "Origin and evolution of the geo-biological system".

\section{Author details}

'College of Life Sciences, Capital Normal University, 105 Xisanhuanbeilu, Haidian District, Beijing 100048, China. ${ }^{2}$ Palaeontological Institute, Russian Academy of Sciences, 123, Profsoyuznaya ul, Moscow 117997, Russia.

${ }^{3}$ Department of Palaeontology, Natural History Museum, Cromwell Road, London SW7 5BD, UK.

Received: 11 February 2014 Accepted: 4 June 2014

Published: 17 June 2014

\section{References}

1. Rasnitsyn AP: Origin and evolution of lower hymenoptera. Trans Paleontol Inst Acad Sci USSR 1969, 123:1-196 (in Russian).

2. Rasnitsyn AP: Origin and evolution of hymenoptera. Trans Paleontol Inst Acad Sci USSR 1980, 174:1-192.

3. Rasnitsyn AP: Fossil hymenoptera of the superfamily pamphilioidea. Paleontol J 1983, 2:56-70.

4. Grimaldi DA, Engel MS: Evolution of the Insects. New York: Cambridge University Press; 2005.

5. Rasnitsyn AP: Late jurassic hymenoptera of karatau. Paleontol J 1963, 1:86-99 [In Russian]. 
6. Rasnitsyn AP: New Mesozoic Sawflies (Hymenoptera, Symphyta). In Jurassic Insects of Karatau. Edited by Rohdendorf BB. Moscow: Nauka Press; 1968:190-236

7. Rasnitsyn AP: An outline of evolution of the hymenopterous insects (order vespida). Orient Insects 1988, 22:115-145.

8. Rasnitsyn AP, Zhang HC, Wang B: Bizarre fossil insects: web-spinning sawflies of the genus Ferganolyda (vespida, pamphilioidea) from the middle jurassic of daohugou, Inner Mongolia, China. Paleontology 2006, 49:907-916.

9. Taeger A, Blank SM, Liston AD: World catalog of symphyta (hymenoptera). Zootaxa 2010, 2580:1-1064.

10. Gao TP, Engel MS, Blanco JO, Shih CK, Ren D: A new xyelydid sawfly from the early cretaceous of China (hymenoptera: xyelydidae). J Kansas Entomol Soc 2013, 86(1):78-83.

11. Ren D, Guo ZG, Lu LW, Ji S, Tang F, Jing YG, Fang XS, Ji Q: A further contribution to the knowledge of the upper jurassic yixian formation in Western Liaoning. Geological Rev 1997, 43:449-459.

12. Zhou ZH, Barrett PM, Hilton J: An exceptionally preserved lower cretaceous ecosystem. Nature 2003, 421:807-814.

13. Ren D, Shih CK, Gao TP, Yao YZ, Zhao YY: Silent Story - Insect Fossil Treasures from Dinosaur era of the Northeastern China. Beijing: Science Press; 2010.

14. Zhang $H$, Wang B, Fang $Y$ : Evolution of insect diversity in the Jehol Biota. Sci China Earth Sci 2010, 53(12):1908-1917.

15. Zhang WT, Yao YZ, Ren D: New shore bug (hemiptera, heteroptera, saldidae) from the early cretaceous of China with phylogenetic analyses. Zookeys 2011, 130:185-198.

16. Gao TP, Shih CK, Xu X, Wang S, Ren D: Mid-mesozoic flea-like ectoparasites of feathered or haired vertebrates. Curr Biol 2012, 22:732-735.

17. Gao TP, Shih CK, Rasnitsyn AP, Ren D: Hoplitolyda duolunica gen. et sp. nov. (insecta, hymenoptera, praesiricidae), the hitherto largest sawfly from the Mesozoic of China. PLoS One 2013, 8(5):e62420

18. Shih CK, Feng H, Liu CX, Zhao YY, Ren D: Morphology, phylogeny, evolution and dispersal of pelecinid wasps (hymenoptera: pelecinidae) over 165 million years. Ann Entomol Soc Am 2010, 103:875-885.

19. Shi $X Q$, Zhao $Y Y$, Shih CK, Ren D: New fossil helorid wasps (insecta, hymenoptera, proctotrupoidea) from the jehol biota, China. Cret Res 2013, 41(1):136-142.

20. Martynov AV: Sur les organes facettiques aux ailes des insects. $C R$ Acad Sci, 1924:71-73.

21. Martynov AV: On the facetic organs in the wings of insects. Trudy Leningradskogo Obshchestva estestvoispytatelei 1924, 54(2):5-24. Proceedings of the Leningrad Society of naturalists.

22. Nichols SW, Schuh RT, man. ed: The Torre-Bueno Glossary of Entomology (Revised Edition of A Glossary of Entomology by J. R. de la Torre-Bueno; Including Supplement A by George S. Tulloch). New York: New York Entomological Society \& American Museum of Natural History; 1989. xvii +840.

23. New TR: Neuroptera (Lacewings). In The Insects of Australia: a Textbook for Students and Research Workers (Second Edition). Vol. 1st edition. Edited by CSIRO. Carlton, Victoria: Melbourne University Press; 1991:525-542.

24. Brues CT: A new genus of phoridae from Peru. Psyche 1933, 40:106-112.

25. Jolivet $P$ : Recherches sur les organes facettiques des ailes des insectes (1). Bulletin de l'Institut royal d 1955, 31:1-23.

26. Kristensen NP: The New Zealand scorpionfly (Nannochorista philpotti comb. n.): wing morphology and its phylogenetic significance. J Zoo/ Syst 1989, 27:106-114

27. Minet J, Huang DY, Wu H, Nel A: Early mecopterida and the systematic position of the microptysmatidae (insecta: endopterygota). Ann Soc Entomol France (NS) 2010, 46(1-2):262-270.

28. Martynova OM: Facetic organs on wings of mecoptera. Bull Mos Soc Nat 1949, 24(4):93-95 (in Russian).

29. Novokshonov VG: New Triassic scorpionflies (insecta, mecoptera). in Russian, english summary. Paleontol J 1997, 6:63-70.

30. Ponomarenko AG: Paleozoic members of the megaloptera (insecta). Paleontol J 1977, 1:73-81.

31. Shcherbakov DE: Permian ancestors of hymenoptera and raphidioptera. ZooKeys 2013, 358:45-67. doi:10.3897/zookeys.358.6289.

32. Wang YJ, Liu ZQ, Ren D, Shih CK: A new genus of protosmylinae from the middle jurassic of China (neuroptera: osmylidae). Zootaxa 2010, 2480:45-53.

33. Wang YJ, Liu ZQ, Ren D, Shih CK: New middle jurassic kempynin osmylid lacewings from China. Acta Palaeontol Pol 2011, 56(4):865-869.
34. Liu XY, Wang YJ, Shih CK, Ren D, Yang D: Early evolution and historical biogeography of fishflies (megaloptera: chauliodinae): implications from a phylogeny combining fossil and extant taxa. PLoS One 2012, 7(7):e40345.

35. Forbes WTM: The occurrence of nygmata in the wings of insecta holometabola. Entomol News 1924, 35:230-232.

36. Riek EF: Fossil insects from the triassic beds at Mt. crosby, Queensland. Aust J Zool 1955 1955, 3(4):654-657.

37. Engel MS: A new sawfly from the triassic of Queensland (hymenoptera, xyelidae). Mem Queensland Mus 2005, 51(2):558.

38. Schlüter T: Moltenia rieki n. gen., n. sp. (hymenoptera: xyelidae?), a tentative sawfly from the molteno formation (upper triassic), South Africa. Paleontol J 2000, 74:75-78

39. Lara MB, Rasnitsyn AP, Zavattieric AM: Potrerilloxyela menendezi gen. et sp. nov. From the late triassic of Argentina: the oldest representative of xyelidae (hymenoptera: symphyta) for Americas. Paleontol J 2014, 48(2):182-190

40. Ronquist F: Phylogeny, classification and evolution of the cynipoidea. Zool Scr 1999, 28:139-164.

41. Ronquist F, Klopfstein S, Vilhelmsen L, Schulmeister S, Murray DL, Rasnitsyn AP: A total-evidence approach to dating with fossils, applied to the early radiation of the hymenoptera. Syst Biol 2012, 61:973-999.

42. Shcherbakov DE: Permian ancestors of Hymenoptera. In CIS Symposium on Hymenoptera: 26-29 September 2006. Edited by Rasnitsyn AP, Gokhman VE. Moscow: Moscow State University; 2006. (in Russian).1924.

43. Wiegmann BM, Trautwein MD, Kim J-W, Cassel BK, Bertone MA, Winterton $S L$, Yeates DK: Single-copy nuclear genes resolve the phylogeny of the holometabolous insects. BMC Evol Biol 2009, 7:34-50. PubMed: 19552814.

44. McKenna DD, Farrell BD: 9-genes reinforce the phylogeny of holometabola and yield alternate views on the phylogenetic placement of strepsiptera. PLoS One 2010, 5(7):e11887. doi:10.1371/journal. pone.0011887.

45. Beutel RG, Friedrich F, Hörnschemeyer T, Pohl H, Hünefeld F, Beckmann F, Meier R, Misof B, Michael F, Whiting MF, Vilhelmsen L: Morphological and molecular evidence converge upon a robust phylogeny of the megadiverse holometabola. Cladistics 2011, 27:341-355.

46. Heraty JM, Ronquist F, Carpenter JM, Hawks D, Schulmeister S, Dowling AP, Murray D, Munro J, Wheeler WC, Schiff N, Sharkey MJ: Evolution of the hymenopteran megaradiation. Mol Phylogenet Evol 2011, 60:73-88. doi:10.1016/j.ympev.2011.04.003. PubMed: 21540117.

47. Sharkey MJ, Carpenter JM, Vilhelmsen L, Heraty JM, Liljeblad J, Dowling A, Schulmeister S, Murray D, Deans AR, Ronquist F, Krogmann L, Wheeler WC: Phylogenetic relationships among superfamilies of hymenoptera. Cladistics 2012, 28:80-112. doi:10.1111/j. 1096-0031.2011.00366.x

48. Klopfstein S, Vilhelmsen L, Heraty JM, Sharkey M, Ronquist F: The hymenopteran tree of life: evidence from protein-coding genes and objectively aligned ribosomal data. PLoS One 2013, 8(8):e69344. doi:10.1371/journal.pone.0069344.

49. Rasnitsyn AP, Quicke DLJ (Eds): History of Insects. Dordrecht: Kluwer Academic Publishers; 2002:517.

50. Wang M, Rasnitysn AP, Shih CK, Ren D: Data from: A new Cretaceous genus of xyelydid sawfly illuminating nygmata evolution in Hymenoptera. Dryad Digital Repository 2014. http://datadryad.org/resource/ doi:10.5061/dryad.v561f/1.

doi:10.1186/1471-2148-14-131

Cite this article as: Wang et al:: A new Cretaceous genus of xyelydid sawfly illuminating nygmata evolution in Hymenoptera. $B M C$ Evolutionary Biology 2014 14:131. 